Society for the Anthropology of Work • Policing and Labor

\title{
Disaggregating Work: The \\ Circularity of Violence and \\ Differential Burdens of \\ Policing
}

Pooja Satyogi

Published on: Dec 01, 2020

DOI: 10.21428/1d6be30e.174ea036

License: Creative Commons Attribution 4.0 International License (CC-BY 4.0). 
Maharashtra is the only state in India that is releasing figures on the number of police personnel who have tested positive for COVID-19. ㅁp through September 24, 2020, the number of positive cases in the state's police force had risen to 21,988, with 3,381 active cases, 18,372 recoveries, and 235 lost lives. Maharashtra, the third-largest Indian state in area and the second most populous, has a police force of roughly 195,000 for a population of 123.5 million. With approximately 11 percent of police affected by the virus (compared to just over 1 percent of the total population), it is worth asking what the price of performing police work during a pandemic might be. Higher rates of infection among the police may result from the expansiveness and diversity of police work, which includes crowd management and other tasks that bring officers into close contact with the public.

This essay takes the rate of infection among police as indicative of a differential in the susceptibility of police personnel to the virus. Police personnel around the world are one among many constituencies of workers deemed essential for the purposes of containing and managing the spread of the virus. And, as this recent collection of essays showed, essential workers have found themselves at increased risk for infection. In September 2020, the Government of India released figures on the rate of positive tests among health care workers-doctors, nurses, staffers and hospital cleaners-and for the state of Maharashtra this figure stood at 16 percent. As of the end of the summer, the Indian Medical Association reported that some 4,274 doctors had been infected and 408 had succumbed to the virus.

I bring together figures from these two forms of work-police and health care-to think, more generally, about whether higher rates of infection among police have not gotten as much attention because there has seemingly been a simultaneous intensification in police violence during the pandemic. Rather than conflating or asserting an equivalence between these forms of work, I am using these figures to articulate a concern about policing as work that all too easily gets reduced to its responsibility for endemic violence. In fact, the expansiveness and diversity of police work often takes police themselves by surprise. So how might we disaggregate a series of actions in policing that could tell us something about police work, which may or may not include violence?

For instance, in the Indian city of Delhi, the local police are required to work in collaboration with the local officials of the Municipal Corporation of Delhi on the collection and disposal of garbage from households that have COVID-positive 
members. The first point of contact for the public here is the police, who then activate a network of services for quarantined residents. We might allow that in exceptional times, the nature of work evolves, but what this articulation would miss is the dispersed and disaggregated nature of police work, which often does not get attention when the focus remains on an aggregated and congealed picture of the police as always already imbricated with violence. One might ask: what do particular actions, such as organizing the collection and disposal of possibly contaminated garbage, mean for the nature of police work? How do we understand police work and policing situations that do not index violence? Is it possible that the stability that inheres in the apparently settled meaning of police violence would collapse when we disaggregate the actions that constitute policing situations? What would this do for our definition of policing as agential state violence? Does the certainty of this definition assure us that we will always recognize violence when we see it?

The anxiety of the pandemic, felt both by the state that aspires to manage and control it and by citizens who fear contagion, represents a particularly important moment for understanding what it means for the police to simultaneously be on guard (to save themselves from infection) and to surveil those not being alert enough (to contain the pandemic). These anxious moments of socially distant encounter could turn violent, but the myriad forms of violence at work under these conditions may not always get our attention. COVID-19 marks a heightened state of anxiety, a modifier rather than an absolute determinant.

On the night of July 8, 2020, Constable Sunita Yadav was on patrol in the city of Surat, Gujarat. With a curfew imposed in the city because of the lockdown, the picket duty that was linked to her low rank in the Indian police hierarchy called on her to identify violators of the curfew and to either give fines or allow individuals to cross the picket in emergencies. This particular night, Constable Vadav stopped four men in a car, who were out without masks during curfew hours. Upon inquiring, she determined that the men were out without "genuine reasons." In a televised interview a few days later, she said: 
Movement is allowed during curfew for genuine reasons. But these people did not have a genuine reason. They apologized to me, saying "sorry." I thought of letting them go unpunished but, as per the law, I had to do something. I had no challan slip [official ticket], so I thought a few sit-ups would be enough for their violation of the law.

One of the four men whom Constable Yadav detained called an influential friend, the son of the Gujarat health minister, Kumar Kanani. Kanani's son arrived on the scene in his father's official vehicle, only to be confronted by Yadav. A member of a community policing initiative known as the Friends of Police happened to be on duty with Yadav and filmed part of this confrontation on his mobile phone. What can be heard in the snippets that made it to social media afterward is Yadav taking on the politician's son for threatening her. Later, she can be heard speaking with the minister on the phone and apprising him of the situation, but without giving into either his or his son's defensiveness. She invokes the symbolic power of her uniform (vardi) to register her position as a state official who must not be threatened while discharging her duty. As these snippets went viral, Yadav was hailed by the public as a tough cop standing up to political pressure and performing her duty with integrity. She was nicknamed Lady Singham, borrowing from a popular Hindi film whose protagonist is a male police officer. The word singham means lion.

Two days later, Yadav was transferred in what was seen as a case of the police establishment giving into political pressure. While her popularity on social and news media soared, Yadav, citing lack of support from her superiors, resigned from the police force soon thereafter. With acceptance of her resignation still pending, Yadav gave a series of interviews, recounting the incident and adding that it has caused to her realize that it is not the uniform but rank that matters in the discharge of official duties. Therefore, she set a new career goal of joining the Indian Police Services, which would give her the status of a high-ranking police bureaucrat. Distancing herself from being called Lady Singham, she has maintained that she was merely an ordinary constable doing her duty. Meanwhile, an inquiry has been set up, which means that Yadav's resignation has not yet been accepted while it plays out. On the night of the incident itself, three out of the five men, including Kanani's son, were arrested and then released on bail a day later. 
Not for the first time during the pandemic, exhausting work days for police officials saw a series of discrete actions lead to an escalation. Yet templates of police violence do not adequately capture the complexity of a situation like Yadav's, because the specter of police violence is copresent with other forms of violence against a woman police official. Her low rank in the hierarchy of Indian policing and her subjection to masculine influence-peddling simultaneously signals gender and caste violence, both of which are deeply entrenched in the subcontinent's social life.

Disaggregating police actions in this incident would have to extend to those members of the public and the police bureaucracy who got involved. The event itself could be broken down into stopping and confronting the men, making them do sit-ups as a form of punishment, escalation with the arrival of the politician's son, and threatening and sexualizing the police official. Of these, the point of escalation could have been when Yadav, upon finding that she did not have official fine slips with her, decided to "teach the men a lesson" in ways that mirror how members of upper castes symbolically shame members of lower castes in India. The deployment of corporal punishment on upper-caste men, who are otherwise wielders of Brahminical patriarchy, by a woman of lower rank and caste may have been the point at which things spiraled out of Yadav's control, subjecting her to sexualized degradation in the form of slurs and gestures.

The response of the police as an institution may be gauged from actions internal to the bureaucracy. These would include actions taken against the men who were arrested and then released on bail, but also against Yadav. Here, the incident itself expands, insofar as it acquires a life of its own on social media, and as a range of policing sites and actions get activated (from Yadav on patrol, to the local police station that arrests the men, to police headquarters, to the disciplinary body within the department).

Violence proliferates in this expanded incident. Yadav's decision to make the detained men do sit-ups was emblematic of shaming and parading caste practices, and yet their inversion (by a woman onto male bodies) did not justify the perpetration of violence. When the men begin to threaten her, she retaliates and says that if she could she would beat them up. Violence is directed at her and it takes the form of degrading her as a police official and a woman at the same time. There is also a physical scuffle in which the men attempt to snatch her mobile phone. Violence inheres in processes of accountability as well, the first instance of which was Yadav's immediate transfer and then the launch of inquiries that did not take into account the violence to which she was subjected. I draw this conclusion from the fact that the men were arrested under 
the Indian Penal Code's Section 188 (disobedience of an order duly promulgated by a public servant), 270 (a negligent and malignant act likely to spread infection of a dangerous disease), and 144 (abettor present when an offense was committed), but not under any sections that take into account the dynamics of violence against women.

What is at stake for me with this incident is the movement between an aspiration for a work ethic, rooted in a sense of duty, and public acts of shaming that are inflected with violent symbolism. Layers of violence stack up, making it difficult to disentangle questions of work for an ordinary, low-ranking official and the state violence with which policing is routinely identified. Disaggregating police work and examining the dispersed sites where it unfolds allows us to gauge the circularity of violence, which builds on templates of social exclusion and affords little clarity about whether the police as such are the fountainhead of violence. I want to end by suggesting that when we pay attention to policing labor performed by women, lower-caste officials, and other minorities, we might be surprised by how local circuits of politicized hierarchy play into creating a differential burden of responsible conduct for them. This work of analysis still needs to done.

\section{Acknowledgments}

I would like to thank Sahana Ghosh for her input on this essay.

\section{Author Bio}

Pooja Satyogi is Assistant Professor in the School of Law, Governance, and Citizenship at Ambedkar University in Delhi. She works in the fields of contemporary policing practices and surveillance and security studies. She is currently finalizing her book manuscript, which is entitled Intimate Public Spaces: Policing "Domestic Cruelty" in Women's Units, Delhi.

\section{Preview Image}

Photo by Chris Henry. 